\title{
Risk Management of Social Media Using in Higher Education
}

\author{
Erna Lovita* \\ Department of Accounting \\ Sekolah Tinggi Ilmu Ekonomi Indonesia \\ Jakarta, Indonesia \\ *erna_lovita@stei.ac.id
}

\author{
Gatot Prabantoro \\ Department of Management \\ Sekolah Tinggi Ilmu Ekonomi Indonesia \\ Jakarta, Indonesia \\ gatot_prabantoro@stei.ac.id
}

\begin{abstract}
The use of social media in university is inseparable from social media. This research discusses the importance of organizations that take reactive risk to manage social media, because of financial problems for managing funds needed to overcome problems related to the organization. This research focuses on how organizations especially universities need social media. The information used in this study includes four components, namely: (i) Use of Social Media, (ii) Perceived Use Risk, (iii) Policy Implementation, and (iv) Technical Training and Control. This research uses descriptive research which discusses quantitative, which uses multiple linear regression based method with SPSS Version 25. The data used in this study are primary data. The technique of collecting data uses the method of distributing questionnaires using Google forms. There were 93 respondents from 18 state and private universities in the DKI Jakarta area, namely employees and lecturers from each of these universities. The results in this study indicate that there is an intervening effect that occurs on the influence of the Use of Social Media and Perception of Use Risk on Training and Technical Control through Policy Implementation.
\end{abstract}

Keywords: Use of Social Media, Perceived Use Risk, Policy Implementation, Training and Technical Control

\section{INTRODUCTION}

One characteristic of the globalization era is shown by the increasingly high role of information technology. Internet and social media as the implementation of information technology have become a part of everyday life. Update personal activities, share the latest information, run an online business, and invite others in an activity. Now, people are more likely to use social media as a forum to find information or product reviews. No wonder, at present almost all companies including SMEs tend to advertise, promote and even transact online. As for the consideration using social media is nothing but efficiency and effectiveness, which is having a greater impact on product sales.

This condition is in line with Aditya's statement [1], that the internet is the latest source of information with increasing ecommerce in Indonesia. This statement can be strengthened by statistical data on the development of e-commerce in various countries. A site called We Are Social shows the number of internet users who shop online in Indonesia with sales penetration has reached 24.74 million people [2]. Over the past year, the users have spent US \$ 5.6 billion (around Rp74.6 trillion) to shop at various e-commerce sites. This is also supported by the internet usage in Indonesia which is very massive with $57 \%$ penetration, now internet users in Indonesia reach 132.7 million users. 106 million of them are active social media users. We Are Social Research mentions Indonesia as a country with the largest number of internet users in the world.

The statistical data above mentions the growing number of internet users is also accompanied by an increasing number of users of social media services. Only 79 million last year, that number has now risen to 106 million users. Users who actively use social media on mobile devices have risen from 66 million to 92 million. This fact makes the main reason for the existence of the division of social media and web developers who become one of the divisions in the company proves the importance of this division to increase sales.

The above phenomenon is not only used by companies solely, the education industry especially higher education also cannot avoid the influence of the internet and social media as a means of supporting university marketing. Not only marketing activities, higher education operational activities also greatly utilize the role of the internet and social media [3]. At this time a prospective student who wants to continue his education will be very easy to find information about the college of interest, domestically and abroad. This was done by accessing the university's website via the internet.

The quality and facilities for prospective students have been improved in such a way that several universities have made the registration process possible online. Likewise for old students who register at the beginning of a new semester. Including the concept of conventional education has also undergone many changes after the advent of the internet and social media. The technical model of lectures, library services, making college assignments, filling out study plans at the beginning of the semester and so on have developed using internet technology. So it can be said that most universities in Indonesia have followed the development of internet technology and social media which are expected to make it easier for students to obtain services provided by the campus.

The development of the internet and social media is changing the way organizations in business and in education, both engaging externally with customers and other stakeholders, as well as how they interact and collaborate 
- The company accidentally made a mistake in giving messages/information disseminated through social media.

- Social media accounts can easily be hijacked and run the risk of changing status or changing info that defiles the name of the company.

2) Privacy risks: A social media is used with the aim of making it easier to share any information, with anyone and get quick feedback. But along with the rapid flow of information the following risks emerge:

- Sensitive or confidential company information will easily spread through social media, if there is no screening process in advance.

- Without adequate control in the use of social media, violations of copyright, patents, trademarks, trade secrets, or Intellectual Property Rights will be at risk for the company.

3) Security risks: As the development of information technology, the use of social media also has an impact on data security. Some security risks that companies need to be aware of include:

- Client information data must be safe from the risk of leakage to outside parties, even among internal parties.

- Risk of virus attacks on company data that is entered through the use of social media.

- The threat of hackers who enter through the company's social media network to retrieve confidential company data.

\section{METHODS}

The object of this research is the implementation of risk management using social media at the university. The focus of research is the university management's perception of the use of social media and risk management. The research process was conducted from April 2019 to September 2019 at several universities in the DKI Jakarta area that had used social media. The distribution of questionnaires was carried out in the DKI Jakarta area where there were 3 public universities and 15 private universities participating in this study.

Finally, complete content and organizational editing before formatting. Please take note of the following items when proofreading spelling and grammar:

\section{A. Hypothesis Testing}

Hypothesis testing used in this research is multiple linear regression test and intervening test. Data analysis uses multiple linear regression, which is a statistical technique to model and investigate the effect between two or several independent variables on a response (dependent variable) [11]. Other tests used in this study relating to multiple linear regression analysis, namely: $T$ test is used to determine the effect of each independent variable partially shown by the Coefficients Table. $\mathrm{T}$ test can also be done by looking at the $\mathrm{t}$ value of each variable in the output of regression results using SPSS with a 
2) Hypothesis 2: Perceived Risk of Use improves Training significance of $0.05(\alpha=5 \%)$. If the significance value $>0.05$ then $\mathrm{HO}$ is accepted or $\mathrm{Ha}$ is rejected, it means that the independent variable has no effect on the dependent variable, and if $<0.05$ then $\mathrm{HO}$ is rejected or $\mathrm{Ha}$ is accepted, it means that the independent variable influences the dependent variable [11].

The next test is the coefficient of determination that measures how far the model's ability to explain the variation of the dependent variable. A small Adjusted R2 value means that the ability of the independent variable to explain the dependent variable is very limited. The value is close to one, meaning that the independent variable provides almost all the information needed to predict the dependent variable. In reality, the adjusted R2 value can be negative, although what is desired must be positive.

The path analysis method used to identify the effect of intervening variables. Path analysis is an extension of multiple linear regression analysis, or path analysis is the use of regression analysis to estimate causal relationships between variables (causal models) that have been predetermined based on theory. Basuki [11] said the influence of the independent variables on the dependent variable did not directly occur but through a process of transformation represented by intervening variables.

\section{B. Hypothesis}

1) Hipothesis 1: Social Media Use will encourage Training and Technical Controls on the implementation of social media through Policy Implementation.

Policies regarding social media are made to protect all parties and to direct employees regarding the obligations, prohibitions and consequences of using social media. Policies made by the organization include, at a minimum, the definition of social media, the classification of information, what is permissible and the prohibition on using social media, the explanation of intellectual property rights, and the consequences if the restrictions in the regulation are violated.

Not all employees fall into the category of experts (experts) in using social media, but organizations can improve the ability and alertness of employees through education, facilities provided, and training so that employees use social media intelligently and carefully. Through education and training, employees are expected to increasingly understand the level of responsibility for the information they handle, increase awareness of the use of social media, and minimize the risk of using social media.

Consistent monitoring needs to be done to find out how the application and the impact it has on employees and the organization, and to ensure that all employees adhere to the policies that have been prepared. From the results of monitoring, an evaluation is carried out to monitor whether the policies compiled are still relevant to the applicable regulations of the authorities. Policies also need to be updated to adjust to the development of the situation or the conditions of employees or organizations [12]. and Technical Controls social media implementation through Policy Implementation.

Understanding the risks of using social media encourages management to implement policies for all parties to use social media appropriately. The policy encourages training and the implementation of technical training mechanisms in using social media. One important issue in the distribution of information using social media is the issue of information security which is one of the topics produced by Cunning's research.

\section{RESULTS AND DISCUSSION}

\section{A. The influence of Social Media Use on Training and Technical Control through Policy Implementation.}

Based on the results of testing through the Sobel Test it can be seen with a significant t-count at 0.05 , namely 3.7093> 1.96 (t-table). So it can be concluded that there is an effect of intervening the Policy Implementation variable on the indirect relationship of the Social Media Use and Training and Technical Control variables. This is appropriate based on research conducted by The Social Media Community [13] and Demek [14] the implementation of Social Media Use affects the Training and Technical Control through Policy Implementation.

With testing that has been done, explaining that there is an indirect effect of Social Media Use and Training and Technical Control through Policy Implementation in the application of social media. Although the value of the direct influence of Social Media Use and Training and Technical Control is greater than the indirect effect, it still has an intervening effect. This means that the use of social media and the presence of existing risks encourage company management to implement policies related to the use of social media in institutions.

\section{B. The Effect of Perceived Risk of Use on Training and Technical Control through Policy Implementation}

Based on the results of testing through Sobel Test it can be seen with a significant count at 0.05 , namely $5.0290>1.96(\mathrm{t}-$ table). So it can be concluded that there is an effect of intervening the Policy Implementation variable on the indirect relationship of the Perceived Risk of Use and Training and Technical Control variables. This is appropriate based on research conducted by Meilinda [3] and Demek [14] the existence of Perceived Risk of Use for the use of social media has an effect on Training and Technical Control through Policy Implementation implemented by institutional management.

With testing that has been done, explaining that there is an indirect effect of the Perceived Risk of Use on Training and Technical Control through Policy Implementation in the application of social media. Although the value of the direct influence of the Perceived Risk of Use on Training and an intervening effect. This means that the existence of risks in the application of social media in institutions will encourage the implementation of social media implementation policies by management to optimize the role of social media itself. Technical Control is greater than the indirect effect, it still has 
implementation policies by management to optimize the role of social media itself.

\section{REFERENCES}

[1] A. Aditya, Social Media Nation, Jakarta: Prasetya Mulya Publishing; 2013.

[2] We Are Social. Indonesian Digital Report 2019,2019.

[3] N. Meilinda, "Social Media on Campus: Studi Peran Media Sosial sebagai Media Penyebaran Komunikasi Akademik pada Mahasiswa di Program Studi Ilmu Komunikasi UNSRI," J Soc Media, vol. 2, no. 1, pp. 53-64, 2018.

[4] G.C. Kane, M. Alavi, G. Labianca, and S. Borgatti, "What's different about social media networks? A framework and research agenda," MIS Q, vol. 38, no. 1, pp. 275-304, 2014.

[5] Investis, Social Media for Corporate Communications : A Review of Corporate Social Media Use in the US and the UK, 2015.

[6] M.J. Culnan, P.J. McHugh, and J.I. Zubillaga, "How large U.S. companies can use twitter and other social media to gain business value," MIS Q, vol. 9, no. 4, pp. 243-59, 2010.

[7] J.R. Engen, The Lure of Corporate Social Media, 2012.

[8] Deloitte, Model Risk Management: Driving the value in modelling, 2017.

[9] P. Eddy, Peranan dan Manfaat Sosial Media bagi Perusahaan, 2011.

[10] R. Kasali, Cracking Zone, Jakarta: Gramedia Pustaka Utama, 2011.

[11] A.T. Basuki, Analisis Regresi dalam Penelitian Ekonomi \& Bisnis: Pers, Dilengkapi Aplikasi SPSS \& Eviews, Jakarta: Rajawali Pers, 2016.

[12] D.E. O'Leary, “The Use of Social Media in The Supply Chain : Survey and Extensions. International Systems Accounting, Financial Management," Int Syst Accounting, Financ Manag, vol. 18, no. 1, pp. 121-44, 2011.

[13] The Social Media Community, Social Media and Risk Management [Online] Retrieved from: https://thesocialmediamonthly.com/socialmedia-and-risk-management/.

[14] K.C. Demek, R.L. Raschke, D.J. Janvrin, and W.N. Dilla "Do organizations use a formalized risk management process to address social media risk?," Int J Account Inf Syst, vol. 28, 2018. 